Project Research in

Information Systems 


\section{Information Systems Series}

Series Editor: Professor I.O. Angell

Computer Security Within Organizations

Adrian R. Warman

Developing Information Systems

Concepts, Issues and Practice

Chrisanthi Avgerou and Tony Cornford

Effective Systems Design and Requirements Analysis

The ETHICS Approach

Enid Mumford

General Systems Theory

An Introduction

Lars Skyttner

Information in Action

Soft Systems Methodology

Lynda Davies and Paul Ledington

Information Systems Management

Opportunities and Risks

Ian O. Angell and Steve Smithson

Ourselves and Computers

Difference in Minds and Machines

Aart Bijl

Project Research in

Information Systems

Tony Cornford and Steve Smithson

Systems Design

Ethical Tools for Ethical Change

Enid Mumford

Understanding Information

An Introduction

Jonathan Liebenau and James Backhouse 


\title{
Project Research in Information Systems
}

\section{A Student's Guide}

\author{
Tony Cornford \\ Steve Smithson
}

Department of Information Systems

London School of Economics and Political Science

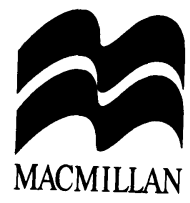




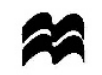

(c) A. Cornford and S. Smithson 1996

All rights reserved. No reproduction, copy or transmission of this publication may be made without written permission.

No paragraph of this publication may be reproduced, copied or transmitted save with written permission or in accordance with the provisions of the Copyright, Designs and Patents Act 1988, or under the terms of any licence permitting limited copying issued by the Copyright Licensing Agency, 90 Tottenham Court Road, London W1P 9HE.

Any person who does any unauthorised act in relation to this publication may be liable to criminal prosecution and civil claims for damages.

First published 1996 by MACMILLAN PRESS LTD

Houndmills, Basingstoke, Hampshire RG21 6XS

and London

Companies and representatives

throughout the world

ISBN 978-0-333-64421-8

DOI 10.1007/978-1-349-13863-0

ISBN 978-1-349-13863-0 (eBook)

A catalogue record for this book is available from the British Library.

$\begin{array}{llllllllll}10 & 9 & 8 & 7 & 6 & 5 & 4 & 3 & 2 & 1\end{array}$

$\begin{array}{llllllllll}05 & 04 & 03 & 02 & 01 & 00 & 99 & 98 & 97 & 96\end{array}$ 
It is beyond the power of the human intellect to encompass all the causes of any phenomenon. But the impulse to search into causes is inherent in man's very nature. And so the human intellect, without investigating the multiplicity and complexity of circumstances conditioning any event, any one of which taken separately may seem to be the reason for it, snatches at the most comprehensible approximation to a cause and says: 'There is the cause!'

War and Peace, Leo Tolstoy 


\section{Contents}

Preface $\quad$ ix

Acknowledgements $\quad$ xi

1 Introduction 1

2 The subject of information systems $\quad 8$

3 Research approaches $\quad 32$

$4 \quad$ Choosing a project $\quad 55$

$\begin{array}{lll}5 & \text { The project and project management } & 73\end{array}$

6 Collecting research data 90

$\begin{array}{lll}7 & \text { Analyzing research data } & 108\end{array}$

8 Writing a project report 136

9 Conclusion $\quad 163$

$\begin{array}{lr}\text { Index } & 173\end{array}$ 


\section{Preface}

Students undertaking research projects within taught information systems courses are the primary audience for this book, in particular final year undergraduate students and masters level students. Beyond this immediate audience we hope that the materials provided here may be of interest and use to a wider group, including those starting out on $\mathrm{PhD}$ or MPhil studies. There is an increased emphasis across all the social sciences on questions of research methodology, research training and the development of academic skills. Most institutions that offer substantial research degree programmes in information systems now provide some formal teaching both in general research methodology and in current research issues in the field. While this book does not claim to provide a comprehensive treatment of all the issues that such courses need to cover, it should provide an introduction to some of the substantive issues that are required to be considered.

The prime motivation for writing this book has been our experience in settingup, supervising and marking student projects. We have also between us, done our share of projects as undergraduate students, postgraduate students and doctoral candidates, and we continue our careers as active researchers. In addition, we have both been external examiners for other universities at all these levels, and have viewed as outsiders the projects of hundreds of students on courses in information systems, business studies and computing. But perhaps the most influential experience for both of us has been our work in advising Masters students on the courses in Analysis, Design and Management of Information Systems (ADMIS) and Information Systems Development (ISD) at the London School of Economics. Over the past five years there have been over 400 students on these courses, and each of them has undertaken at least two projects, including a group project in term time, and a 10,000-word dissertation during the summer period. Each of those projects, almost without exception, has contained useful and insightful material, but most have also been flawed to some degree. We have often seen enthusiasm, good ideas and solid work come to little because of poor planning and a lack of awareness of what it takes to complete and present a project. In other words, we have not seen the perfect project or, if we have, we did not manage to recognize it.

What we have learned, however, is some of the essence of what it takes to produce a good project in the information systems field. In particular, we have 
seen how the strengths and weaknesses of individual student's approaches to project work contributes to the final result. These experiences have convinced us of the need for students to be given guidance as to what it means to do research and what is expected of them in their project work. This needs to be backed up with a clear statement of the criteria against which their work will be assessed. There is also a need for students to be given some support and direction by their teachers during the early stages of project work.

This book cannot be expected to address these requirements completely; that is, it can neither set down a definitive statement of what is expected from projects in a particular institution, nor substitute for the involvement of an experienced and knowledgeable adviser. A book such as this can, however, provide valuable support in attaining these goals. If we have done our job well, it can provide a student with advice and information to help to make their own projects an academic success. Equally importantly, we hope that it can help to make the experience of undertaking a research project personally satisfying.

We also hope that the book can serve as a basis for encouraging teachers and lecturers to adopt a constructive approach to supervising student projects. Teachers in higher education are now under intense pressure; there are more students, more formalities to observe and more pressure to become involved in other aspects of academic life such as personal research, publishing and general administration. There is a danger that student projects may as a result be neglected or downgraded. Yet, it is our experience that a positive approach to projects, particularly in this young discipline of information systems, can be an intellectually and academically satisfying part of a teacher's work.

The pleasure that we have received in working with our own students, and the education that they have provided to us through their project work, leads us to dedicate this book to all our students in the Information Systems Department at LSE, past, present and future.

Tony Cornford

Steve Smithson

Department of Information Systems London School of Economics and Political Science, 1996 


\section{Acknowledgements}

The initial basis of this book was a Course Guide for the Information Systems Project course of the University of London B.Sc (Economics) External Degree pathway in Information Systems and Management. We are very grateful to the External Programme of the University of London for permission to use some material from that publication in this book.

We would also like to thank Godfrey Womudhu-Kyama and Laurence Habib for their help in preparing the manuscript for publication. 